\title{
PERANAN PEMBINAAN DAN PENGAWASAN PADA PENGUSAHAAN AIR TANAH DI UPT DINAS ESDM PROVINSI JAWA BARAT WILAYAH PELAYANAN I CIANJUR
}

\author{
ROLE OF GUIDANCE AND SUPERVISION ON GROUNDWATER \\ MANAGEMENT IN TECHNICAL IMPLEMENTATION UNIT (UPT) \\ DEPARTMENT OF ESDM WEST JAVA PROVINCE AREA SERVICE I \\ CIANJUR
}

\author{
Wawan Setiawan', Abubakar Iskandar ${ }^{2}$, Ginung Pratidina ${ }^{3}$ \\ 1 Jurusan Imu Administrasi Negara Fakultas Ilmu Sosial dan Ilmu Politik Universitas Djuanda, \\ Jl.Tol Ciawi No.1, Kotak Pos 35 Bogor 16770 \\ ${ }^{2}$ Jurusan Imu Administrasi Negara Fakultas Ilmu Sosial dan Ilmu Politik Universitas Djuanda, \\ Jl.Tol Ciawi No.1, Kotak Pos 35 Bogor 16770 \\ ${ }_{3}^{3}$ Jurusan Imu Administrasi Negara Fakultas Ilmu Sosial dan Ilmu Politik Universitas Djuanda, \\ Jl.Tol Ciawi No.1, Kotak Pos 35 Bogor 16770 \\ ${ }^{4}$ Korespondensi: Wawan Setiawan Email : wawan.setiawan@gmail.com
}

(Diterima oleh Dewan Redaksi: 01-02-2018)

(Dipublikasikan oleh Dewan Redaksi: 01-04-2018)

\begin{abstract}
Bogor Regency is one of the regencies and municipalities in the working area of UPT ESDM Department of Service Area I Cianjur which has many licenses of groundwater exploitation, this can be seen from the existing data in the area of Bogor Regency in December 2016 there are 745 companies holding water business license soil.

This study aims to determine the role of guidance and supervision in groundwater exploitation in the Technical Implementation Unit of the Department of Energy and Mineral Resources (UPTDESDM) West Java Province Service Area I Cianjur. With working areas including: Cianjur, Sukabumi, Sukabumi, Bogor, Bogor and Depok.

According to Pratowo (2001) the success of groundwater management is highly dependent on supervisory and control functions, including coaching function. Ivancevich put forward a number of important points, namely, coaching is a systematic process to change the work behavior of a / group of employees in an effort to improve organizational performance. George R.Terry (2006: 395) defines oversight as disseminating what has been done, that is to evaluate work performance and if necessary apply corrective action action so that the result of work according to the plan has been determined. Business is the process, the way, the act of cultivating and organizing. Groundwater or so-called ground water is water located beneath the soil surface in the zone or water-saturated layer. Methodology of this research uses descriptive research design with qualitative approach method. The unit of analysis in this research is in the form of individual / informant. The research informants were chosen by purposive sampling, while the technique used in this research are: Observation, Interview, and Documentation.

Based on research result show that the role of guidance and supervision towards license holder of groundwater in terms of water quality analysis is categorized as "quite good" or "quite effective".
\end{abstract}


Recommendation for Office of UPT Department of ESDM West Java Province Service Area I Cianjur is the Office must continue to run coaching and supervision for the preservation of water resources, especially ground water remain awake and sustainable.

Keywords: Guidance, Monitoring and Operation of ground water.

\begin{abstract}
ABSTRAK
Kabupaten Bogor merupakan salah satu dari Kabupaten dan Kota yang ada di wilayah kerja UPT Dinas ESDM Wilayah Pelayanan I Cianjur yang banyak memiliki izin pengusahaan air tanah, ini dapat dilihat dari data yang ada di wilayah Kabupaten Bogor Bulan Desember 2016 terdapat 745 perusahaan pemegang izin pengusahaan air tanah.

Penelitian ini bertujuan untuk mengetahui peranan pembinaan dan pengawasan dalam pengusahaan air tanah di Unit Pelaksana Tehnik Dinas Energi Sumber Daya Mineral (UPTDESDM) Provinsi Jawa Barat Wilayah Pelayanan I Cianjur. dengan wilayah kerja diantaranya : Kabupaten Cianjur, Kabupaten Sukabumi, Kota Sukabumi, Kabupaten Bogor, Kota Bogor dan Kota Depok.

Menurut Pratowo (2001) keberhasilan pengelolaan air tanah sangat tergantung pada fungsi pengawasan dan pengendalian termasuk fungsi pembinaan. Ivancevich mengemukakan sejumlah butir penting yaitu, pembinaan adalah sebuah proses sistematis untuk mengubah perilaku kerja seorang/sekelompok pegawai dalam usaha meningkatkan kinerja organisasi. Georgr R.Terry (2006:395) mengartikan pengawasan sebagai menderteminasi apa yang telah dilakukan, maksudnya mengevaluasi prestasi kerja dan apabila perlu menerapkan tindakan tindakan korektif sehingga hasil pekerjaan sesuai dengan rencana yang telah ditetapkan. Pengusahaan adalah proses, cara, perbuatan mengusahakan dan menyelenggarakan. Air bawah tanah atau yang biasa disebut sebagai air tanah adalah - air yang terletak di bawah permukaan tanah pada zona atau lapisan jenuh air. Metodologi Penelitian ini mengunakan desain penelitian deskriptif dengan metode pendekatan kualitatif. Adapun unit analis dalam penelitian ini adalah berupa individu / informan. Informan penelitian dipilih secara purposive sampling, Sedangkan teknik teknik yang digunakan dalam penelitian ini adalah : Observasi, Wawancara, dan Dokumentasi. Hasil dan pembahasannya: 1.Pemeriksaan/ analisa kualitas air tanah, 2. Data pengambilan air tanah, 3.Pajak air tanah, 4.Pertimbangan tehnik izin pengambilan air tanah

Saran penulis agar Kantor UPT Dinas ESDM Provinsi Jawa Barat Wilayah Pelayanan I Cianjur harus terus menjalankan pembinaan dan pengawasan agar kelestarian sumber daya air khususnya air tanah tetap terjaga dan lestari.
\end{abstract}

Kata kunci :Pembinaan, Pengawasan dan Pengusahaan air tanah

Wawan Setiawan, 2017, Peranan pembinaan dan pengawasan dalam pengusahaan air tanah di UPT Dinas ESDM Wilayah I Cianjur 


\section{PENDAHULUAN}

Peranan Dinas Energi dan Sumber Daya Mineral ( Dinas ESDM ) Provinsi Jawa Barat dalam kegiatan kerja dan pelayanannya adalah melaksanakan urusan bidang yang meliputi :

1. Air Tanah

2. Pertambangan

3. Energi

4. Ketenagalistrikan

Perkembangan pandangan baru dalam pengelolaan pemerintahan sekarang, dengan desentralisasi, berdasar pada nilainilai demokrasi, pelayanan dan pemberdayaan, yang bisa berdampak pada terwujudnya suatu Pemerintah Daerah yang mempunyai keleluasaan dalam pengambilan keputusan yang paling baik dan mampu mengoptimalkan potensi yang ada di daerah tersebut, sehingga bisa memberikan mutu pelayanan publik yang optimal kepada rakyatnya.

Dinas Energi dan Sumber Daya Mineral Provinsi Jawa Barat dalam optimalisasi pelayanannya telah membentuk 5 (lima) UPT Dinas ESDM Provinsi Jawa Barat yang tersebar di beberapa wilayah pelayanan di Jawa Barat. Salahsatunya adalah UPT DINAS ESDM Wilayah Pelayanan I Cianjur yang berkedudukan Jl. Ir. H. Juanda Km.3 No.61 Panembong - Cianjur dengan memiliki wilayah kerja diantaranya : Kabupaten Cianjur, Kabupaten Sukabumi, Kota Sukabumi, Kabupaten Bogor, Kota Bogor dan Kota Depok.

Salah satu pelayanan bidang sumber daya mineral yang dilaksanakan yaitu pengawasan dan pembinaan pengusahaan air tanah di Seksi Sumber Daya Mineral.

Kabupaten Bogor adalah salahsatu dari Kabupaten dan Kota yang ada di UPT Dinas ESDM Wilayah Pelayanan I Cianjur yang banyak memiliki izin pengusahaan air tanah, ini bisa dilihat dari data di wilayah Kabupaten Bogor bulan Desember 2016 terdapat 745 perusahaan pemegang izin pengusahaan air tanah dengan jumlah titik sumur sebanyak 1.349 titik, pengusahaan air sebanyak 2.378.453 m3 dan NPA 22.126.605.050.51 (Data NPA Bulan Desember 2016 Dinas ESDM Kabupaten Bogor).

Sumber daya air dinilai sangat penting bagi kehidupan dan kesejahteraan rakyat Indonesia maka Pemerintah Indonesia mengaturnya didalam pasal 33 ayat 3 Undang-Undang Dasar 1945 Negara Republik Indonesia yang berbunyi: "Bumi air dan kekayaan alam yang terkandung di dalamnya dikuasai oleh negara dan dipergunakan untuk sebesar-besar kemakmuran rakyat" Pasal ini berfungsi sebagai dasar hukum peraturan yang ada di bawahnya yang mengatur tentang pengelolan sumber daya alam (termasuk sumber daya air) yaitu UU No.11 Tahun 1974 tentang Pengairan dan PP No.121 Tahun 2015 Tentang Pengusahaan Sumber Daya Air.

Berdasarkan pengamatan awal yang telah dilakukan bahwa terdapat beberapa permasalahan yang ditemui antara lain masih kurangnya pemahaman dari pemegang izin pengambilan air tanah terhadap peraturan perundangan yang berlaku.

Hal ini dapat ditunjukkan dari masih banyaknya pengguna air tanah yang belum melaksanakan kewajiban kewajiban sebagai pemegang izin pengusahaan air tanah. Kewajiban kewajiban Pemegang Izin Pengusahaan Air Tanah yang dimaksud dalam PP No.121 Tahun 2015 mengenai Pengusahaan Sumber Daya Air ayat (1) adalah :

1. Mematuhi ketentuan dalam izin;

2. Menyampaikan setiap bulannya laporan debit pengusahaan Air Tanah kepada gubernur;

3. Memasang meteran Air di setiap sumur produksi yang berlaku untuk pengusahaan Air Tanah;

4. Membangun sumur resapan air di tempat yang ditetapkan oleh Gubernur;

5. Berpartisipasi di dalam penyediaan sumur pantau Air Tanah;

6. Memberikan lima belas persen (15\%) dari batasan debit pengusahaan Air 
Tanah yang telah ditetapkan di dalam izin bagi pemenuhan keperluan pokok masyarakat lokal.

Dari 6 (enam) wilayah kerja yang berada dalam Wilayah Pelayanan I Cianjur adalah Kabupaten Bogor paling banyak dalam daftar pemegang izin pengusahaan air tanah dan juga merupakan salah satu terbanyak di wilayah provinsi jawa barat.

\section{TINJAUAN PUSTAKA}

\section{Menurut Pratowo (2001) bahwa} keberhasilan dalam manajemen air tanah tergantung sekali pada fungsi pengendalian, pengawasan dan pembinaan. Pengawasan merupakan aktivitas yang dilaksanakan supaya menjamin tegaknya aturan perundang-undangan pengelolaan air bawah tanah, meliputi pemantauan terhadap air bawah tanah agar dalam pemanfaatannya tidak berakibat negatif terhadap lingkungan serta untuk menjaga ketersediaan dan mutunya.

Berdasarkan Keputusan Menteri Energi Dan Sumberdaya Mineral No. 1451. K/10/MEM/2000 tentang Pedoman teknis penyelenggaraan tugas pemerintahan di bidang manajemen air tanah. Manajemen air tanah adalah pengelolaan dalam makna luas melingkupi segala usaha untuk inventarisasi, pengaturan dan pemanfaatan, pembinaan, perizinan, pengendalian dan pengawasan serta konservasi air tanah.(repository.usu.ac.id/bitstream/1234 56789/33658/4/Chapter\%20II)

\section{METODE PENELITIAN}

Desain penelitian ini merupakan penelitian metode deskriptif dengan pendekatan kualitatif. Penelitian ini dipilih bertujuan menyajikan data secara faktual, sistematis dan akurat mengenai fakta-fakta yang ada di tempat penelitian.

Dengan menggunakan desain penelitian deskriptif dengan pendekatan kualitatif bertujuan untuk menggali sebanyak banyaknya tentang fakta mengenai peranan pembinaan dan pengawasan dalam pengusahaan air tanah oleh UPT DINAS ESDM Provinsi Jawa Barat Wilayah pelayanan I Cianjur.

\section{Subyek Penelitian}

Dengan landasan pengertian diatas subjek penelitian ini adalah yaitu Kepala UPT Dinas ESDM Provinsi Jawa Barat Wilayah Pelayanan I Cianjur sebagai pimpinan semua kegiatan di kantor UPT Dinas ESDM Wilayah Pelayanan I Cianjur , Kepala Tata Usaha (KaT.U) dan Kepala Seksie Sumber Daya Mineral ( SDM) sebagai kunci informan (key Informan) dikarenakan sebagai pejabat dan kepala seksi yang melaksanakan kegiatan pembinaan dan pengawasan dalam pengusahaan air tanah di wilayah pelayanan I Cianjur.

\section{Implikasi Teoritis}

Pengawasan terhadap pengusahaan air tanah seperti yang dicantumkan di dalam Peraturan Pemerintah No.121 Tahun 2015 dibagian Kedua tentang Pengawasan atas Pengusahaan Air Tanah Pasal 48, Pasal 49, Pasal 50, Pasal 51, Pasal 52, Pasal 53, Pasal 54, Pasal 55, Pasal 56, Pasal 57, Pasal 58.

Mengingat sebaran dan potensi air tanah di alam tidak merata, maka agar penggunaannya bisa kontinyu tanpa menciptakan kerusakan negatif lingkungan di dalam setiap pemanfaatan dan pengambilannya harus mempertimbangkan kemampuan akuifer dalam memasok air. Konsep cekungan air tanah sebagai kesatuan wilayah pengelolaan air tanah didasarkan kepada prinsip terciptanya air tanah yang utuh di dalam satu neraca air dimulai dari daerah imbuhan hingga ke daerah lepasan (luahan) pada suatu wadah, yakni cekungan air tanah.

Berdasarkan konsep ini bisa diketahui dengan terukur semua potensi air tanah dalam suatu cekungan air tanah, termasuk kemampuan penyediaan air tanah dari akuifer yang terdapat dalam cekungan tersebut. Dengan melaksanakan pengelolaan didasarkan pada cekungan air tanah, seluruh aktivitas manajemen air tanah yang terdiri dari konservasi, inventarisasi, pendayagunaan air tanah, dan pengendalian daya rusak air tanah 
mencakup aktivitas pemberdayaan, pengawasan dan pengendalian air tanah bisa direncanakan dan diimplementasikan dengan baik. ESDM - Kepmen ESDM Tentang Penetapan Daerah Penghasil dan Dasar Penghitungan Dana Bagi Hasil SDA Migas Tahun 2016

\section{Implikasi Praktis}

Dalam pengelolaan air tanah, beberapa hal penting dalam pembinaan dan pengawasan dalam pengusahaan air tanah antara lain:

1. penambahan dan Pengadaan jumlah sumur pantau supaya mengetahui perubahan-perubahan kondisi dan situasi air tanah akibat pengambilan sebagai tindak lanjut dalam mengambil keputusan pengelolaan air tanah.

2.Pembuatan sumur sumur imbuhan sebagai kelestarian sumber daya air tanah. ( Daerah imbuhan air tanah adalah daerah resapan air yang mampu menambah air tanah secara alamiah pada cekungan air tanah).

3. Penertiban sumur-sumur pengambilan air tanah yang tidak memiliki izin, sebagai salahsatu usaha untuk mencegah tercemarnya air.

Mengenai pengaturan dalam Manajemen Sumber Daya Air, di tanggal 18 Februari 2015. Mahkamah Konstitusi (MK) memberikan kebijakan Putusan Nomor 85/PUU-XI/2013 atas penggugatan pengujian materi yang kedua kepada Undang-Undang Nomor 7 Tahun 2004 mengenai Sumber Daya Air. Putusan itu antara lain menyampaikan bahwa UndangUndang Nomor 7 Tahun 2004 tentang Sumber Daya Air tidak memiliki kekuatan hukum dan memberlakukan kembali Undang-Undang No. 11 Tahun 1974 mengenai Pengairan. Berkaitan dengan hal itu, harus dilakukan pengaturan mengenai Pengusahaan Sumber Daya Air yang sesuai dengan kondisi pada saat ini. Hal ini sejalan dengan Putusan Mahkamah Konstitusi yang mengungkapkan bahwa salahsatu makna penguasaan Air oleh Negara adalah melakukan pengaturan (regelendaad).
Dalam Putusan Mahkamah Konstitusi tersebut terkandung 6 (enam) prinsip utama dan mendasar mengenai pembatasan Pengelolaan Sumber Daya Air yang antara lain menyatakan "... pemberian izin Pengusahaan Sumber Daya Air kepada usaha swasta dapat dilakukan dengan syarat-syarat tertentu dan ketat ...". Prinsip tersebut mengandung arti bahwa di dalam Manajemen Sumber Daya Air, aktivitas Pengusahaan Sumber Daya Air oleh badan usaha swasta merupakan prioritas terakhir, oelh karena itu persyaratan tertentu dan ketat bisa diimplementasikan Pengusahaan Sumber Daya Air tidak hanya syarat dalam permohonan izin tetapi juga berarti bagian dari seluruh aspek dalam penyelenggaraan Pengelolaan Sumber Daya Air.

Dengan demikian pengaturan mengenai persyaratan tertentu dan ketat harus diatur mulai dari pengaturan penyusunan rencana penyediaan Sumber Daya Air yang merupakan sebagian dari perencanaan Pengelolaan Sumber Daya Air, prioritas adalah pemberian izin, prioritas perpindahan Air, dan kontrol pelaksanaan aktivitas Pengusahaan Sumber Daya Air serta pemberian sanksi dalam rangka penegakan hukum. Pengaturan dalam perizinan dan alokasi Air dibutuhkan sebab ketersediaan Air secara alami tidak berbanding lurus dengan jumlah penduduk yang semakin banyak. Sehubungan dengan hal tersebut, persaingan antara kebutuhan Air bagi pemenuhan kebutuhan pokok sehari-hari dengan kebutuhan Air untuk penggunaan lainnya, termasuk kegiatan pengusahaan yang memerlukan sumber daya Air, di masa depan akan semakin meningkat. Untuk menjamin pemanfaatan dan pemakaian Air yang adil dan merata diperlukan pengaturan perizinan dan alokasi Air, baik bertujuan pemenuhan keperluan pokok dalam sehari-hari dan pertanian masyarakat serta Pengusahaan Sumber Daya Air.

Perizinan dalam Pengelolaan Sumber Daya Air diselenggarakan dengan maksud untuk memberika perlindungan terhadap hak rakyat atas Air, pemenuhan 
kebutuhan para pengguna Sumber Daya Air dan perlindungan terhadap Sumber Daya Air. Tidak bisa dihindari bahwa untuk memenuhi kebutuhan kita pada kondisi ini paling utama pada masa-masa yang akan datang tidak terbatas untuk memenuhi kebutuhan primer saja, yaitu pemenuhan kebutuhan pokok sehari-hari serta pertanian masyarakat, akan tetapi mencakup kebutuhan untuk memenuhi yang sekunder, contohnya transportasi, energi, pariwisata, olah raga dan lain-lain. Upaya untuk terpenuhinya kebutuhan sekunder ini, seringkali memerlukan dukungan SDA (Sumber Daya Air) melalui aktivitas Pengusahaan Sumber Daya Air.

Agar terlindunginya hak masyarakat atas air dan prioritas memenuhi kebutuhan air bagi aktivitas usaha maka dari itu aktivitas Pengusahaan SDA (Sumber Daya Air) harus dilaksanakan berdasarkan Izin Pengusahaan SDA (Sumber Daya Air) ataupun Izin Pengusahaan Air Tanah.

Izin Pengusahaan SDA (Sumber Daya Air) diberikan apabila Air untuk memenuhi kebutuhan pokok pertanian rakyat dan kebutuhan sehari-hari telah dipenuhi, juga sepanjang tersedianya Air masih cukup. Izin Pengusahaan SDA (Sumber Daya Air) atau Izin Pengusahaan Air Tanah diberikan oleh Pemerintah Daerah atau Pemerintah Pusat yang relevan dengan kewenangan masingmasing.

Jumlah batas Air yang ditetapkan dalam Izin Pengusahaan SDA tidak bersifat mutlak dan tidak wajib dipenuhi seperti yang tercantum di dalam izin. Kuota Air diberikan atas dasar ketersediaan Air dan prioritas alokasi Air. Selain itu, kuota Air yang ditetapkan di dalam izin bisa ditinjau kembali jika keadaan atau persyaratan yang dijadikan dasar pemberian izin dan kondisi ketersediaan Air pada Sumber Air yang bersangkutan mengalami perubahan yang berarti sekali.

Perizinan merupakan instrumen pengendali agar mewujudkan ketertiban di dalam Pengelolaan SDA, melindungi hak rakyat dalam memenuhi kebutuhan pertanian rakyat dan kebutuhan pokok sehari-hari, serta sistem irigasi yang ada bisa menjamin hak ulayat masyarakat hukum adat setempat atas Air dan hak yang serupa dengan hal tersebut. (Penjelasan PP RI No. 121 Tahun 2015 Mengenai Pengusahaan SDA).

\section{HASIL DAN PEMBAHASAN}

Dasar Hukum Pembentukan UPTD ESDM Wilayah I Cianjur adalah; Peraturan Gubernur No. 75 Tahun 2009 mengenai Pedoman Pembentukan UPTD (Unit Pelaksana Teknis Dinas) dan UPTB (Unit Pelaksana Teknis Badan) Berita Daerah Tahun 2009 Nomor 148 Seri E. Perannya sebagai pelaksana terbawah di Dinas Energi dan Sumber Daya Mineral Provinsi Jawa Barat berkaitan dengan tugas pokoknya dalam mengimplementasikan sebagian fungsi Dinas dibidang konservasi, pelayanan, dan pelestarian sebagian urusan bidang energi dan sumber daya mineral yang meliputi, Pertambangan, Air Bawah Tanah, Kegeologian, Ketanaga Listrikan, Energi baru terbarukan, Migas, dan Panas Bumi.

\section{Peranan Pembinaan dan Pengawasan Air Tanah dalam Pengusahaan Air Tanah \\ Peranan pembinaan dan} pengawasan air tanah merupakan bentuk pelayanan publik terhadap pengambil air tanah dan bentuk penegakan konservasi air tanah. Setiap birokrasi publik perlu berupaya untuk memberikan peranannya yang terbaik kepada masyarakat pengguna layanan, seperti dalam hal ini kegiatan yang dilaksanakan oleh kantor UPT Dinas ESDM Provinsi Jawa Barat wilayah pelayanan I Cianjur dalam peranannya melaksanakan kegiatan pembinaan dan pengawasan air tanah dalam pengusahaan air tanah. Upaya untuk meningkatkan kesadaran dan kewajiban para pengguna air tanah terus dilakukan ke arah yang lebih baik dengan lebih efisien dan efektif. Peranan pembinaan dan pengawasan air tana masih terus dilaksanakan seiring kewenangan-nya dalam pengelolaan air tanah dan konservasi air tanah. 


\section{Hambatan-hambatan Pengusahaan Air Tanah}

Peranan pembinaan dan pengawasan air tanah menghadapi beberapa permasalahan dalam proses penyelenggaraan pelaksanaannya, yang antara lain sebagai berikut :

a. Sumber Daya Aparatur

Memberikan pelayanan yang maksimal kepada masyarakat atau badan usaha sangat dibutuhkan aparatur pemerintah yang memadai. Jumlah pegawai yang ada di seksi sumber daya mineral ada 8 orang, terdiri dari 1 orang kepala seksi dan 9 orang staf.

Dari ke sembilan orang staf tersebut masing masing memiliki tanggung jawab wilayah sesuai cakupan wilayah yang masuk ke dalam UPT Dinas ESDM Wilayah Pelayanan I Cianjur. tetapi walau begitu dengan jumlah personil yang ada tidak mengurangi kegiatan pembinaan dan pengawasan air tanah.

b. Kesadaran pengguna air tanah

Salah satu faktor yang turut mempengaruhi pelaksanaan pembinaan dan pengawasan air tanah adalah faktor kesadaran pengguna air tanah. Kesadaran dimaksudkan ialah kesadaran untuk mempersiapkan segala yang menjadi persyaratan untuk melakukan suatu urusan pengusahaan air tanah, relasi antara aparat pemerintah dengan pengguna air tanah akan saling mendukung dalam kegiatan pengusahaan air tanah dengan tetap menjaga konservasi air tanah agar tetap lestari.

c. Prasarana penunjang

Di jaman teknologi yang sedang maju saat ini penggunaan alat alat teknologi yang canggih dilapangan sangatlah penting untuk mendeteksi dan menganalisa pengambilan air yang tidak sesuai debit izin yang berlaku atau tidak sesuai dengan jumlah titik sumur yang dilaporkan.

\section{Upaya penyelesaian dalam menangani hambatan}

1. Sumber Daya Aparatur

Luasnya cakupan wilayah kerja yang masuk di dalam wilayah kegiatan UPT Dinas ESDM Provinsi Jawa Barat Wilayah Pelayana I Cianjur harus di imbangi dengan jumlah pegawai yang memadai dan ahli.

Kurangnya jumlah pegawai dalam menyeimbangi luasnya wilayah kerja di siasati dengan melaksanakan dua agenda pemeriksaan dan pembuatan berita acara pemeriksaan lapangan dalam satu tujuan ke perusahaan, artinya bila ada kegiatan pemeriksaan untuk survei permohonan izin pengusahaan air tanah dapat dibarengi dengan kegiatan pembinaan dan pengawasannya. Untuk meningkatkanan sumber daya manusianya UPT Dinas ESDM Provinsi Jawa Barat Wilayah Pelayanan I Cianjur selalu mengirimkan pegawainya untuk mengikuti diklat, bimbingan tehnik dan ikut studi banding.

1. Kesadaran pengguna air tanah

Kestabilan dan kelestarian sumber daya air tanah merupakan tanggung jawab bersama antara pengguna air tanah maupun pemerintah.

Kesadaran pengguna air untuk menghemat air dan melaksanakan kewajiban kewajiban sebagai pemegang izin pengusahaan air tanah haruslah tetap menjadi bagian dalam peransertanya didalam konservasi air tanah.

2. Prasarana penunjang

Peranan pembinaan dan pengawasan air dalam pengusahaan air tanah merupakan kegiatan pemantauan terhadap pelaksanaan izin pengusahaaiatn air tanah. Kegiatan tersebut haruslah didukung oleh prasaran penunjang yang memadai dan sesuai kebutuhan. Pemenuhan prasana pendukung tidak lepas dari anggaran yang diajukan dan disetujui. Walau 
bagaimanapun semua itu tidaklah mengurangi efektifitas kegiatan dengan memanfaatkan fasilitas yang ada.

\section{PEMBAHASAN \\ Analisa Kualitas Air Tanah}

Salah satu kewajiban pemegang izin pengusahaan air tanah adalah melaksanakan pemeriksaan kualitas air tanah ke laboratorium, hal ini bertujuan untuk mengetahui kandungan atau farameter yang terdapat dalam air tanah selain itu juga bertujuan untuk menetapkan nilai kualitas air tersebut ke dalam perhitungan Nilai Perolehan Air (NPA) untuk penetapan pajak air tanah. Pemeriksaan kualitas air tanah yang disarankan dapat dilaksanakan tidak hanya di Laboratorium Dinas ESDM akan tetapi di laboratorium manapun yang telah terakreditasi KAN atau Komite Akreditasi Nasional untuk Laboratorium air tanah.

Pemeriksaan kualitas air tanah yang tidak masuk ke laboratorium Dinas ESDM tidak dapat direkapitulasi penerimaan sample air untuk analisa kualitas air oleh UPT Dinas ESDM, tetapi hal ini akan menjadi pekerjaan pembinaan dan pengawasan ke depan untuk menyarankan agar pemegang izin pengusahaan air dapat melaksanakan pemeriksaan kualitas air tanah ini bisa memeriksakan kualitas airnya ke laboratorium Dinas ESDM Provinsi Jawa Barat. Menurut data yang terdapat di kantor UPTDESDM Wilayah pelayanan I Cianjur, Jumlah penerimaan sampel air yang masuk untuk dianalisa kualitas air pada Tahun 2014 sebanyak 349 sampel air.

\section{Data Pengambilan Air Tanah}

Pengusahaan air tanah yang diimplementasikan adalah kegiatan pengambilan air yang telah memiliki hak pengusahaan air tanah yaitu pemegang izin pengusahaan air tanah.

Data pemegang izin di wilayah provinsi jawa barat pada tahun 2014 sekitar 7.394 titik sumur bor dan 190 juta meter kubik air tanah dieksploiyasi. (Kepmen ESDM Tentang Penetapan Daerah Penghasil dan Dasar Penghitungan Dana Bagi Hasil SDA Migas Tahun 2016) .

Kabupaten Bogor merupakan salah satu dari Kabupaten dan Kota yang ada di UPT Dinas ESDM Wilayah Pelayanan I Cianjur yang banyak memiliki izin pengusahaan air tanah, ini dapat dilihat dari data yang ada di wilayah Kabupaten Bogor bulan Desember 2016 terdapat 745 perusahaan pemegang izin pengusahaan air tanah dengan jumlah titik sumur sebanyak 1.349 titik, pengusahaan air sebanyak 2.378.453 m3 dan NPA 22.126.605.050.51 (Data NPA Bulan Desember 2016 Dinas ESDM Kabupaten Bogor ).

Data tersebut merupakan data pemegang izin pengusahaan air tanah sekaligus sebagai pemegang npwp pajak air tanah.Penetapan Nilai Perolehan Air (NPA) Wilayah pengambilan air tanah di Kabupaten Bogor terbagi dalam wilayah kecamatan, Dimana ada beberapa wilayah kecamatan yang masuk dalam daftar pemegang izin pengusahaan air tanah paling banyak dikarenakan wilayah tersebut adalah daerah industri.

\section{Pajak Air Tanah}

Berdasarkan Peraturan Bupati Kabupaten Bogor No.74 Tahun 2010 tentang Tata cara perhitungan Nilai Perolehan Air tanah.

Peraturan Bupati No.74 Tahun 2000 adalah peraturan yang mengatur tentang tata cara perhitungan pungutan pajak air tanah, dasar pengenaan pajak air tanah adalah Nilai Perolehan Air tanah.

Komponen komponen Sumber Daya Alam (SDA) terdiri dari :

1.Zona pengambilan

2.Mutu air

3.keberadaan sumber air alternatif

4.Jenis sumber air

Komponen sumber daya alam merupakan komponen yang dipengaruhi oleh kondisi lingkungan tempat pengambilan air tanah berada.

Setiap Unsur-unsur sunber daya alam akan diberikan nilai indeks sebagai berikut : 
(1) Nilai unsur zona pengambilan air ditetapkan sebagai berikut:
1.Zona kritis
$: 2,6$
2.Zona rawan
$: 1,1$
3.Zona aman
$: 0,3$

(2) Nilai unsur mutu air ditetapkan sebagai berikut:

$\begin{array}{ll}\text { 1.Kelas satu } & : 1,9 \\ \text { 2.Kelas dua } & : 0,9 \\ \text { 3.Kelas Tiga dan Empat } & : 0.2\end{array}$

(3) Nilai unsur sumber alternatif ditetapkan sebagai berikut:
1.PDAM
$: 1,3$
2.Air Permukaan
$: 0,6$
3.Tidak ada alternatif
$: 0,1$

(4)Nilai unsur jenis sumber air ditetapkan sebagai berikut:
1. Air Tanah Dalam
$: 0,8$
2. Air Tanah Dangkal
$: 0,2$

\section{Komponen-Komponen Pemulihan}

Komponen-komponen

\section{Kompensasi}

pemulihan adalah komponen yang memberikan deskripsi tentang kontribusi dari pengambil air dalam usaha pemulihan sumber daya.

Indeks besarnya nilai komponen kompensasi pemulihan ditentukan oleh tujuan pengambilan dan atau pemanfaatan air tanah dan jumlah volume air yang telah diambil.

Wilayah Kecamatan tersebut diantaranya: Kecamatan Gunungputri, Kecamatan Cileungsi, Kecamatan Citeureup dan Kecamatan Cibinong

\section{KESIMPULAN}

Sebab-sebab kunci yang bisa menentukan kesuksesan pembangunan, yaitu kemampuan Sumber Daya Manuasia, kehandalan organisasi, regulasi yang terbuka dan menyeluruh serta ketersediaan pembiayaannya. Sebab-sebab tersebut akan menjadi indikator yang urgen dari aspek penyelenggaraan pemerintahan, selain penyebab eksternal (lingkungan strategis) yang harus diperhatikan. Kunci penting yang lain yaitu kerjasama dan sinergisitas, baik antar pemerintahan maupun antara pemerintah dan masyarakat. banyak sekali aspek dari Sektor Energi dan Sumber Daya Mineral yang harus diperhatikan dan dikelola secara sinergis, untuk mencapai optimalisasi pencapaian tujuan pembangunan pertambangan, energi dan pengelolaan air tanah. Peran Dinas Energi dan Sumber Daya Mineral insi Jawa Barat melalui UPT Dinas ESDM Wilayah Pelayanan I Cianjur merupakan langkah akselerasi pencapaian tujuan pembangunan Energi dan Sumber Daya Mineral di Indonesia umumnya, serta mendukung pembangunan daerah di Provinsi Jawa Barat khususnya. Berdasarkan hasil penelitian dan pembahasan yang telah dilakukan mengenai Peranan pembinaan dan pengawasan dalam pengusahaan air tanah di Kantor UPT Dinas ESDM Wilayah Pelayanan I Cianjur dapat diambil kesimpulan sebagai berikut :

1. Berdasarkan hasil penelitian yang dilakukan peranan pembinaan dan pengawasan terhadap kewajiban pemegang izin pengusahaan air dalam hal analisa kualitas air tanah sudah cukup baik, ini dapat dilihat dari data penerimaan sampel air pada tahun 2014 sebanyak 349 sampel dengan 176 sampel untuk wilayah Kabupaten Bogor, hal ini menyimpulkan ada hasil baik dikarenakan pemeriksaan kualitas air tidak ada suatu ketetapan hukum yang menunjuk salah satu laboratorium untuk menjadi tempat analisa kualitas air, jadi ada kebebasan pihak pemegang izin dalam memilih laboratoriumnya dengan standar akreditasi nasional.

2. Dalam pembayaran pajak air tanah, semua pemegang hak izin pengusahaan air tanah yang telah mengantongi izin pengusahaan air telah mengantongi NPWP pajak air tanah yang tertulis dalam Surat Ketetapan Pajak Daerah (SKPD) pajak air yang dikeluarkan oleh Dinas Pendapatan yaitu sebanyak 745 perusahaan untuk wilayah Kabupaten Bogor. 
Berdasarkan kesimpulan di atas, maka penulis dapat memberikan saran sebagai berikut:

1. Kantor UPT Dinas ESDM Provinsi Jawa Barat Wilayah Pelayanan I Cianjur tetap terus menjalankan pembinaan dan pengawasan agar kelestarian sumber daya air khususnya air tanah tetap terjaga dan lestari.

2. Menambah inovasi baru untuk meningkatkan program pembinaan dan pengawasan untuk membantu penyebaran dan pemahaman informasi kepada pelaku pengambilan air tanah.

\section{DAFTAR PUSTAKA}

Sugiono, 2014. Metode Penelitian Kuanlitatif Kualitatif R\&D: Cetakan ke 20

Lexy J. Moleong, Metode Penelitian Kualaitatif Bandung: Remaja Rosdakarya.

Lubis, H Ibrahim. 1985. Pengendalian dan Pengawasan Proyek dalam Manajemen. Jakarta: Ghalia Indonesia.

Dr. Ir. Basuki Hadimuljono, MSc., 2005. Menuju Pengelolaan Sumber daya Air Terpadu Dalam Rangka Implementasi Undang-undang Sumber daya Air.

Satrio Hadipurwo, 2006. Konservasi Air Tanah, Direktorat Pembinaan Pengusahaan Panas Bumi Dan Pengelolaan AirTanah. Bandung.

Hasibuan. S.P. Malayu. 2007. Manajemen Sumber Daya Manusia. Jakarta: Bumi Aksara.

Soemarto, 1989. Air adalah air yang menempati rongga-rongga dalam lapisan geologi

Poerdarminta. 1996. Pembinaan adalah pembangunan atau pembaharauan Dalam Kamus Umum Bahasa Indonesia: (1996:327). Diambil dari ,http://repositoryupi.edu/operator/u pload/ssdt06081588chapter2.pdf
Terry. 2004. Istilah "control" dikutip oleh Muchsan (dalam Fachruddin 2004:88)

Kamus Ekabahasa Resmi Bahasa Indonesia. Pengertian Pengusahaan

Republik Indonesia. 1974. Undang-Undang No.11 Tahun 1974 Tentang Pengairam. Lembaran Negara RI Tahun $1974 \quad$ No.11.Sekretatis Negara.Jakarta

Republik Indonesia. 2014. Undang-Undang No 23 Tahun 2014 Tentang Pemerintahan Daerah.Lembaran Negara RI Tahun 2014. Sekretaris Negara.Jakarta

Peraturan Pemerintah Tentang Pengusahaan Sumber Daya Air, PP No.121 Tahun 2015

Keputusan Menteri ESDM Tentang Penetapan Daerah Penghasil dan Dasar Penghitungan Dana Bagi Hasil SDA Migas, Kepmen Tahun 2016 https://t.co/kZOlje9YWf Copyright (C) 2016 Dinas Energi dan Sumber Daya Mineral Provinsi Jawa Barat. All Rights Reserved. 